\title{
THE INFLUENCE OF THE THICKNESS OF THE ELASTIC SPHERICAL SHELL WITH LIQUID ON ITS STRESS-STRAIN STATE
}

\author{
Oleksii Sheptylevskyi
}

\author{
Mykolaiv National Agrarian University, Mykolayiv, Ukraine
}

\begin{abstract}
Summary. Investigations of the dynamics of the system consisting of elastic spherical shell filled with ideal compressible fluid and gas cavity in the center of the system are presented in this paper. The excitation pulsemodulated source is introduced into the gas cavity in the center of the system. The effect of the shell thickness on its dynamics and the stress-state during the pulsations is investigated. The results for radial displacements changes of the middle surface, the thickness of the fluid separation from the shell, the stress intensity in the shell during its free pulsations are obtained. The comparison of calculations for the separation thickness in cases of free and partially fixed shell is carried out.
\end{abstract}

Key words: hydroelasticity, gas cavity, spherical wave, elastic spherical shell, interaction of environments, liquid separation, shell surface movement.

Statement of the problem. At the present stage of its development, mathematical science provides a powerful apparatus for the investigation of the processes occurring in the physical world systems. Modeling of such processes is rather important for various branches of science, technology, production [1-3]. The approach based on the investigation of mathematical models results in the optimization of sophisticated technical systems operation, increase of safety and reliability of their functioning, promotes their research and improvement. In modern complex systems, it is difficult, and sometimes even impossible, to obtain accurate solutions by means of analytical methods. Therefore, at the present stage of investigations, numerical methods are widely used.

Analysis of available investigation results. In various fields of science and technology we can find the investigated hydroelastic system [4], consisting of elastic spherical shell filled with an ideal compressible fluid. While storing liquefied gas under pressure, as well as flammable substances, spherical tanks are used. Spherical tanks are part of the technological lines equipment in chemical industry. Similar mathematical models are also used in biomechanics [5-7]. Moreover, spherical shells are used in explosive chambers for modeling and research of explosive processes [4]. Similar systems are considered in papers [8-13], where the problems of the dynamics of filled shells are solved, but problems related to the influence of shell thickness on its dynamics and stress state are important and require further investigations.

Objective of the paper is to investigate the influence of the thickness of the shell filled with ideal liquid on its stress-strain state in the process of its radial pulsations, both for free shell and for partially fixed one.

The object of the investigation in this paper is hydroelastic mechanical system, consisting of closed spherical shell filled with liquid with a gas cavity in the center. The subject of the investigation is the dependence of the dynamics and stress state of the shell on its thickness. 
Statement of the task. The problem of hydroelasticity for spherical shell $S$ with thickness $h$ filled with ideal compressible liquid in the area $\Omega$ with gas cavity in the center in the area $\Omega^{c}$, which is the source of system excitation when energy is introduced into it, is presented (Fig. 1 a). We assume that elastic shell is in contact with the external acoustic environment in the area $\Omega^{a}$.

A spherical coordinate system, where each point of space is defined by three coordinates $M(\theta ; \varphi ; R)$ is introduced. $R_{s}$ is the radius of the middle surface of the spherical shell, on the surface of which each point is set by two coordinates - polar angles. The shell motion (elementary platform) is described by five variables: displacements in space $(u ; v ; w)$ and angles of rotation relatively to the normal $\left(\theta^{*} ; \varphi^{*}\right)$ (Fig. $1 \mathrm{~b}$ ).

By the time $t=0$ the system is at rest. From the moment of time $t=0$, the wave motion is excited in the system. This moment is transmitted from the spherical cavity to the liquid and further to the elastic shell and is emitted into the external environment.

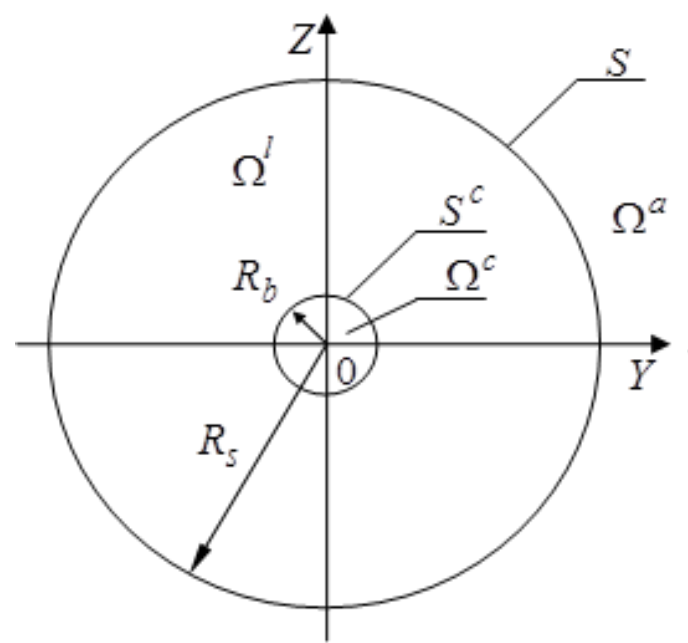

al

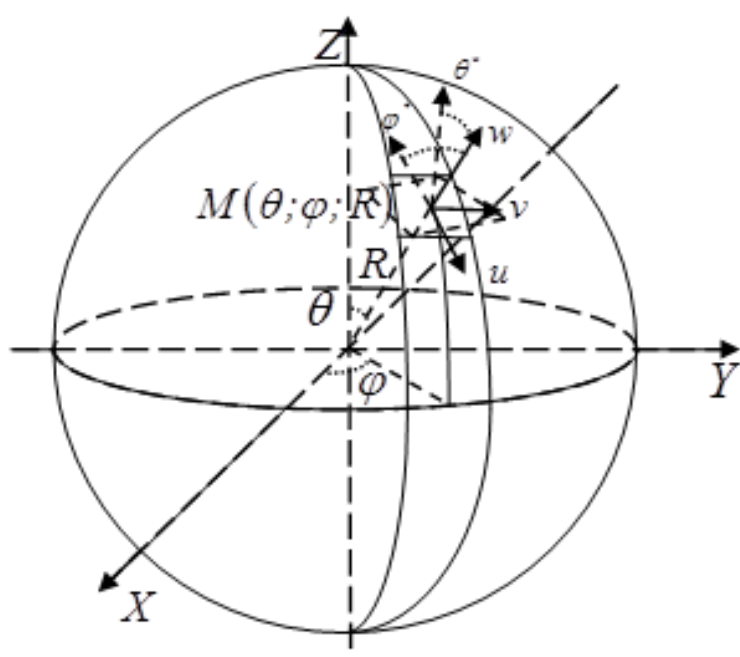

bi

Figure 1. System geometry

The system of equations obtained in paper [4], which describes the dynamics of the hydroelastic system «cavity-liquid-shell», is reduced to the dimensionless form. The primary variables are the period of natural oscillations of the shell in vacuum $T_{s}$, the shell radius $R_{s}$, the shell material density $\rho_{s}$. Variable systems presented in dimensionless form in this paper are denoted by the symbol « ». In this case, the linear values and densities are as follows:

$$
\begin{gathered}
\tilde{R}_{s}=1, u=R_{s} \cdot \tilde{u}, v=R_{s} \cdot \tilde{v}, w=R_{s} \cdot \tilde{w}, \\
h=R_{s} \cdot \tilde{h}, R_{b}=R_{s} \cdot \tilde{R}_{b}, \tilde{\rho}_{s}=1, \rho_{l}=\rho_{s} \cdot \tilde{\rho}_{l},
\end{gathered}
$$

where $R_{b}$ is gas cavity radius, $h$ is the shell thickness, $\rho_{l}$ is the liquid density.

Then the transition formulas for different physical and geometric variables to dimensionless variables are as follows: 


$$
\begin{gathered}
P=\frac{\rho_{s} R_{s}^{2}}{T_{s}^{2}} \tilde{P}, \varepsilon_{i j}=\tilde{\varepsilon}_{i j}, \chi_{i j}=\frac{1}{R_{s}} \tilde{\chi}_{i j}, T_{i j}=\frac{\rho_{s} R_{s}^{3}}{T_{s}^{2}} \tilde{T}_{i j}, M_{i j}=\frac{\rho_{s} R_{s}^{4}}{T_{s}^{2}} \tilde{M}_{i j}, Q_{i}=\frac{\rho_{s} R_{s}^{3}}{T_{s}^{2}} \tilde{Q}_{i}, \\
\sigma_{i j}=\frac{\rho_{s} R_{s}^{2}}{T_{s}^{2}} \tilde{\sigma}_{i j}, f=\frac{R_{s}^{2}}{T_{s}} \tilde{f}, E=\frac{\rho_{s} R_{s}^{2}}{T_{s}^{2}} \cdot \tilde{E},
\end{gathered}
$$

where $P$ is the pressure magnitude, $f$ is the liquid potential, $\varepsilon, \chi$ are the magnitudes of deformations and rotations of the middle shell surface, $T, M$ are forces and moments applied to the middle surface, $Q$ are cutting forces.

The dynamics of gas cavity (at $0<r \leq \tilde{R}_{b}$ ) is determined by energy balance equation [14], which during the transition to the dimensionless form is as follows:

$$
\frac{1}{\gamma-1} \frac{4}{3} \pi \tilde{R}_{b}^{3} \frac{d \tilde{P}_{b}}{d t}+\frac{\gamma}{\gamma-1} \tilde{P}_{b} 4 \pi \tilde{R}_{b}^{2} \frac{d \tilde{R}_{b}}{d t}=\tilde{N}(t)
$$

where $\tilde{R}_{b}, \tilde{P}_{b}$ is the radius of cavity and pressure in it, $\gamma$ is the adiabatic index, $\tilde{N}(t)$ is energy power.

The boundary conditions determining the interaction of liquid and gas cavity, in dimensionless form is the following:

$$
\tilde{P}_{b}=\tilde{P}^{*} ; \frac{d \tilde{R}_{b}}{d \tilde{t}}=\left.\frac{d \tilde{f}^{l}}{d \tilde{r}}\right|_{r=R_{b}}
$$

The liquid dynamics (at $\tilde{R}_{b}<r<\tilde{R}_{s}$ ) in the acoustic approximation is determined by the wave equation in spherical coordinate system (6), the pressure in the liquid is determined by the Cauchy-Lagrange equation in dimensionless form (5):

$$
\tilde{P}=\tilde{P}_{0}-\tilde{\rho}_{l} \frac{\partial \tilde{f}}{\partial \tilde{t}}
$$

and the wave equation is as follows:

$$
\frac{\partial^{2} \tilde{f}}{\partial \tilde{t}^{2}}=C_{1}\left[\frac{1}{\tilde{r}^{2}} \frac{\partial}{\partial \tilde{r}}\left(\tilde{r}^{2} \frac{\partial \tilde{f}}{\partial \tilde{r}}\right)+\frac{1}{\tilde{r}^{2} \sin \theta} \frac{\partial}{\partial \theta}\left(\sin \theta \frac{\partial \tilde{f}}{\partial \theta}\right)++\frac{1}{\tilde{r}^{2} \sin ^{2} \theta} \frac{\partial^{2} \tilde{f}}{\partial \varphi^{2}}\right]
$$

where $C_{l}=c^{2} \frac{T_{s}^{2}}{R_{s}^{2}}$ is the dimensionless complex.

Conditions at the boundary of liquid and shell are the following:

$$
\tilde{q}_{3}=\left.\tilde{P}^{l}\right|_{r=1}-\left.\tilde{P}^{a}\right|_{r=1} ; \frac{d \tilde{w}}{d \tilde{t}}=\left.\frac{d \tilde{f}^{l}}{d \tilde{r}}\right|_{r=1} .
$$


The dynamics of elastic spherical shell is described by the equations of its motion in the spherical coordinate system [15] and determines the dependence of displacements $(\tilde{u}, \tilde{v}, \tilde{w})$ and rotation angles $(\tilde{\theta} ; \tilde{\varphi})$ of the elementary platform of the shell on the forces and moments $\left(\tilde{T}_{i j}, \tilde{Q}_{i}, \tilde{M}_{i j}\right)$ :

$$
\begin{gathered}
\frac{\partial \tilde{T}_{11}}{\partial \theta}+\frac{1}{\sin \theta} \frac{\partial \tilde{T}_{12}}{\partial \varphi}+\left(\tilde{T}_{11}-\tilde{T}_{22}\right) \operatorname{ctg} \theta+\tilde{Q}_{1}+\tilde{q}_{1}=\tilde{h} \frac{\partial^{2} \tilde{u}}{\partial \tilde{t}^{2}} ; \\
\frac{\partial \tilde{T}_{12}}{\partial \theta}+\frac{1}{\sin \theta} \frac{\partial \tilde{T}_{22}}{\partial \varphi}+2 \tilde{T}_{12} \operatorname{ctg} \theta+\tilde{Q}_{2}+\tilde{q}_{2}=\tilde{h} \frac{\partial^{2} \tilde{v}}{\partial \tilde{t}^{2}} \\
\frac{\partial \tilde{Q}_{1}}{\partial \theta}+\frac{1}{\sin \theta} \frac{\partial \tilde{Q}_{2}}{\partial \varphi}+\tilde{Q}_{1} \operatorname{ctg} \theta-\tilde{T}_{11}-\tilde{T}_{22}+\tilde{q}_{3}=-\tilde{h} \frac{\partial^{2} \tilde{w}}{\partial \tilde{t}^{2}} ; \\
\frac{\partial \tilde{M}_{11}}{\partial \theta}+\frac{1}{\sin \theta} \frac{\partial \tilde{M}_{12}}{\partial \varphi}+\left(\tilde{M}_{11}-\tilde{M}_{22}\right) \operatorname{ctg} \theta=\tilde{Q}_{1}+\frac{\tilde{h}^{3}}{12} \frac{\partial^{2} \tilde{\theta}^{*}}{\partial \tilde{t}^{2}} \\
\frac{\partial \tilde{M}_{12}}{\partial \theta}+\frac{1}{\sin \theta} \frac{\partial \tilde{M}_{22}}{\partial \varphi}+2 \tilde{M}_{12} \operatorname{ctg} \theta=\tilde{Q}_{2}+\frac{\tilde{h}^{3}}{12} \frac{\partial^{2} \tilde{\varphi}^{*}}{\partial \tilde{t}^{2}},
\end{gathered}
$$

where $q_{i}$ are the components of the total pressure on the middle surface and completing physical and geometric relations are the following:

$$
\begin{array}{ccc}
\tilde{\varepsilon}_{11}=\frac{\partial \tilde{u}}{\partial \theta}+\tilde{w} ; & \tilde{\chi}_{11}=\frac{\partial \theta^{*}}{\partial \theta} \\
\tilde{\varepsilon}_{22}=\left(\frac{1}{\sin \theta} \frac{\partial \tilde{v}}{\partial \varphi}+\tilde{u} \operatorname{ctg} \theta+\tilde{w}\right) ; & \tilde{\chi}_{22}=\left(\frac{1}{\sin \theta} \frac{\partial \varphi^{*}}{\partial \varphi}+\theta^{*} \operatorname{ctg} \theta\right) \\
\tilde{\varepsilon}_{12}=\frac{1}{2}\left(\frac{1}{\sin \theta} \frac{\partial \tilde{u}}{\partial \varphi}+\frac{\partial \tilde{v}}{\partial \theta}-\tilde{v} \operatorname{ctg} \theta\right) ; & \tilde{\chi}_{12}=\left(\frac{1}{\sin \theta} \frac{\partial \theta^{*}}{\partial \varphi}-\varphi^{*} \operatorname{ctg} \theta-\frac{\partial \tilde{v}}{\partial \theta}\right) ; \\
\tilde{\varepsilon}_{13}=\frac{1}{2}\left(\frac{\partial \tilde{u}}{\partial \tilde{R}}-\tilde{u}+\frac{\partial \tilde{w}}{\partial \theta}\right) ; & \tilde{M}_{11}=\frac{\tilde{E} \tilde{h}^{3}}{12\left(1-v^{2}\right)}\left(\tilde{\chi}_{11}+v \tilde{\chi}_{22}\right) ; \\
\tilde{\varepsilon}_{23}=\frac{1}{2}\left(\frac{1}{\sin \theta} \cdot \frac{\partial \tilde{w}}{\partial \varphi}+\frac{\partial \tilde{v}}{\partial \tilde{R}}-\tilde{v}\right) ; & \tilde{M}_{22}=\frac{\tilde{E} \tilde{h}^{3}}{12\left(1-v^{2}\right)}\left(\tilde{\chi}_{22}+v \tilde{\chi}_{11}\right) \\
\tilde{T}_{11}=\frac{\tilde{E} \tilde{h}}{1-v^{2}}\left(\tilde{\varepsilon}_{11}+v \tilde{\varepsilon}_{22}\right) ; & \tilde{M}_{12}=\frac{\tilde{E} \tilde{h}^{3}}{12(1+v)} \tilde{\chi}_{12} ; \\
\tilde{T}_{22}=\frac{\tilde{E} \tilde{h}}{1-v^{2}}\left(\tilde{\varepsilon}_{22}+v \tilde{\varepsilon}_{11}\right) ; & \tilde{Q}_{1}=\frac{\tilde{E} \tilde{h}}{1+v} \tilde{\varepsilon}_{13} ; \\
\tilde{T}_{12}=\frac{\tilde{E} \tilde{h}}{1+v} \tilde{\varepsilon}_{12} ; & \tilde{Q}_{2}=\frac{\tilde{E} \tilde{h}}{1+v} \tilde{\varepsilon}_{23} .
\end{array}
$$

The conditions at the shell-gas boundary are:

$$
\frac{d \tilde{w}}{d \tilde{t}}=\left.\frac{\partial \tilde{f}^{a}}{\partial \tilde{r}}\right|_{r=1} ;\left.\tilde{P}^{a}\right|_{r=1}=\tilde{q}_{3}+\tilde{P}_{0}
$$


Building solutions. While constructing the system solution, the finite difference method is used, a spatial grid with fixed step along the radial coordinate ( $\Delta r$ ) and along the coordinate angles in the spherical coordinate system $(\Delta \theta, \Delta \varphi)$ is constructed. The time step $(\Delta t)$ is determined by Courant-Friedrichs-Levy conditions. The solutions are constructed by means of successive approximations, reducing the radial step of the spatial grid. According to the system parameters, the geometric radial step is $\Delta \tilde{r}=0,013$, respectively, $\Delta u, \Delta v$ are determined at each radial step and change at during the removal from the origin.

In order to construct the solution of gas cavity dynamics (3), two-layer Euler-Cauchy method, applying the algorithm proposed in paper [16] is used. The radius of the cavity, its pressure and the liquid potential on the boundary with the cavity are determined at each time step. The solutions of the wave equation (6) and system (8) are obtained by means of threelayer "cross" time scheme and geometric sampling [4, 17] (Fig. 2).

The transition to discrete analogues in system (8) makes it possible to express the shell displacement $\left(u_{i j}^{n+1} ; v_{i j}^{n+1} ; w_{i j}^{n+1}\right)$ and its rotation angles $\left(\theta_{i j}^{* n+1} ; \varphi_{i j}^{{ }^{*} n+1}\right)$ at each point of the sampling area by variables on the previous time layer.

In order to take into account the geometric nonlinearity of the cavity pulsations while constructing the problem solution for moving boundary, the approach proposed in paper [9] is used. This approach makes it possible to take into account the displacement of the cavity surface relatively to the nodes of spatial grid division by fixed geometric step. During the interaction of liquid and elastic shell, the separation of liquid from the shell and cavity formation at the media distribution boundary is possible.

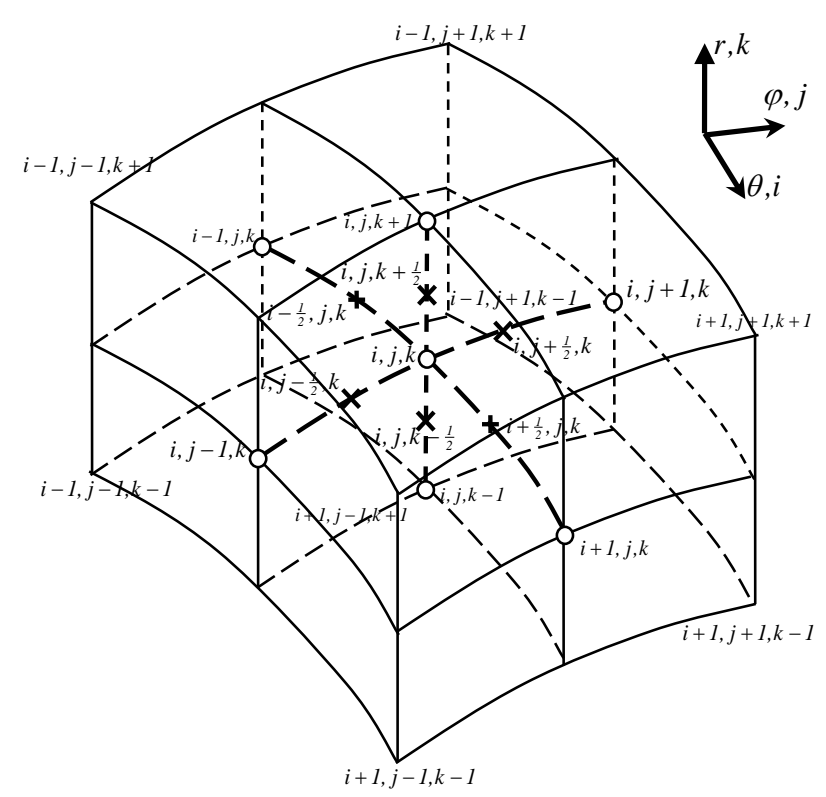

Figure 2. Spatial grid of the finite difference method

Analysis of the obtained results. In order to determine the regularities of the influence of shell thickness on its dynamics and stress state, the closed spherical steel shell with radius $R_{s}=0,3 \mathrm{~m}$, thickness $1 \mathrm{~mm} \leq h \leq 1 \mathrm{sm}$ in the external gaseous medium is considered. Its dynamics is determined by the wave equation (6) and conditions (10). The shell is filled with water under atmospheric pressure. At the initial moment of time, the system is in the equilibrium state, which is disturbed by pulsed energy introduction $E_{0}=500 \mathrm{~J}$ into the gas cavity $R_{b 0}=1 \mathrm{~mm}$ located in the center of the system during time $t_{o}=0,16 \mathrm{~s}$. When energy is introduced, the gas cavity begins to expand and transfers part of the received energy to the 
liquid, where the spherical pressure wave, propagating from the system center to the shell is formed.

When energy is transferred from the liquid to the shell, its middle surface begins to move and stress state occurs in the shell. When the free shell moves (in the absence of fixation), the stress-strain state of the shell is determined by its radial displacements. If the shell thickness is increased, the amplitude of its pulsations decreases. The dynamics of radial displacements of the middle shell surface under the influence of hydrodynamic processes in the liquid is shown in Fig. 3. Radial displacements are characterized by low-frequency and high-frequency components, the former are caused by the pulsation of gas cavity and changes in liquid pressure, and the latter are caused by the movement of spherical pressure wave in the liquid volume. The regularities of these components ratio are revealed in paper [18]: with the shell thickness increase, the amplitude of cavity pulsations of decreases and the relative amplitude of highfrequency components increases.

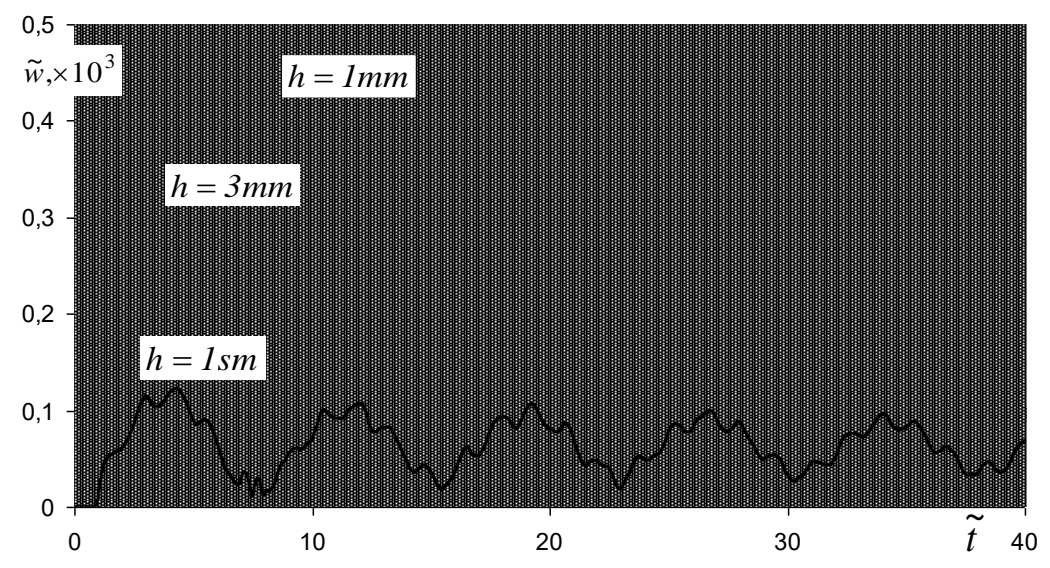

Figure 3. Radial displacement of the shell

Moreover, the stress intensity and the dynamics of the shell are influenced by cavitation phenomena at the boundary of media distribution. These phenomena occur when the liquid separates from the shell, the algorithm for the calculation of separation layer thickness is described in paper [19].

In the process of system pulsations, the amplitude of oscillations of its radial displacements decreases with time, pulsating relatively to a certain average value. The shell thickness increase results in this process acceleration (Fig. 3). As we can seen, the maximum value of the first pulsation decreases with the shell thickness increase, and at $\tilde{h}>17 \times 10^{-3}$ the maximum values of the second and third ones almost coincide.

Radial pulsations of the shell (Fig. 3) at first minimum have increased amplitudes of high-frequency components which for $h=1 \mathrm{~mm}$ are evident. Such amplitude increase

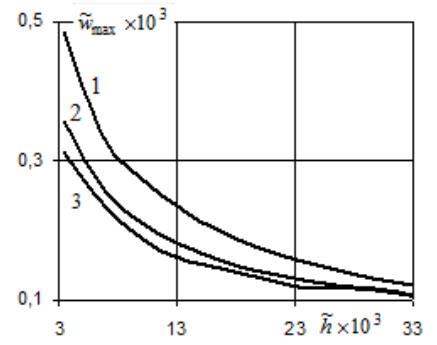

Figure 4. Maximums of radial pulsations is associated with phenomena occurring on the interface, i. e. as the result of the liquid separation from the shell and cavity formation on media interface. Such cavitation phenomena at the boundary are short-term, and when the cavity collapses at the boundary, the pressure shock wave occurs, resulting in pressure jumps at the boundary and, as a consequence, the shell displacements increase. 
The formation of liquid separation from the shell and the cavity formation at the interface is due to the mobility of the boundaries of liquid and shell and the internal pressure in the system. The occurrence of separation is observed at the minimum pressure values in the system. It occurs during the compression phase of the gas cavity in the center during the increase of liquid volume the system (Fig. 5). If shell thickness is increased, its mobility decreases and the formation of separation on subsequent pulsations is not observed (Fig. 5, $\tilde{h}=3 \cdot 10^{-2}$ ).
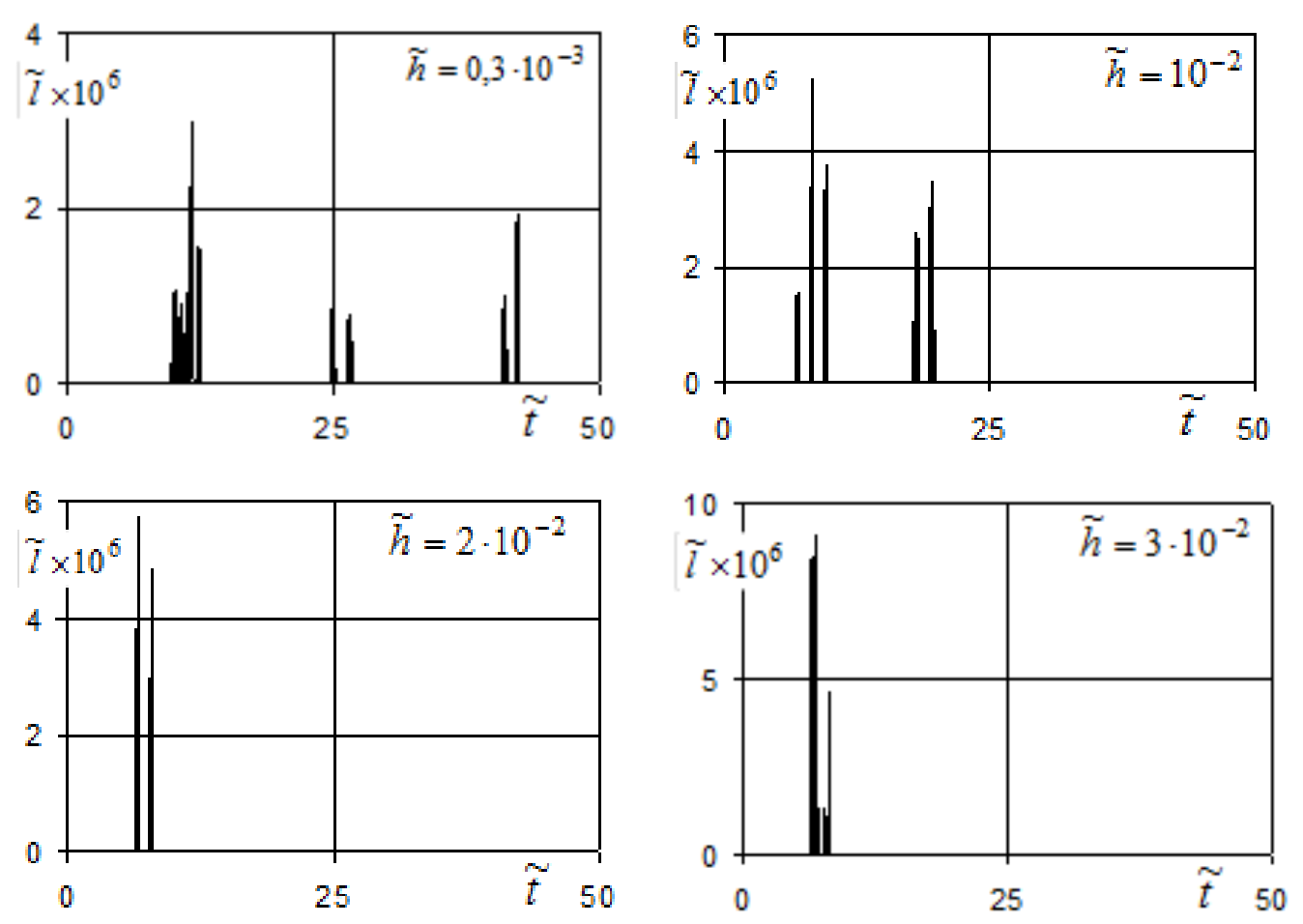

Figure 5. The thickness of the separation layer at different values of shell thickness

The change in the intensity of free shell stresses depends on its radial pulsations and shell thickness. If shell thickness is increased, the stress intensity decreases, corresponding to the dynamics of shell movements changes.

The stresses intensity depends significantly on the pulsations number. The intensity of stresses of the first pulsation significantly exceeds the value of the intensity of the subsequent ones.

While fixing the shell on the surface part, the intensity of stresses, dynamics, the thickness of the separation layer significantly vary depending on the distance from the fixing area. The results of the calculations for separation layer thickness at rigidly fixed surface of the shell with thickness $\tilde{h}=0,3 \cdot 10^{-3}$ at the North Pole for $\theta<\pi / 20$ are presented in Fig. 6 . The dynamics of the thickness of separation layer at the given point is in average two orders of magnitude greater than the corresponding thickness of separation layer during the free shell pulsation. Such dynamics is caused by the presence of shell pulsations asymmetry causing occurrence of longitudinal and transverse elastic waves in the shell, as well as wave phenomena in the liquid on the interface of the shell and liquid, during the waves propagation the phenomenon of their focusing at certain points occurs. Waves focusing results in the increase of the shell surface displacements, which in turn leads to the stress intensity increase. 

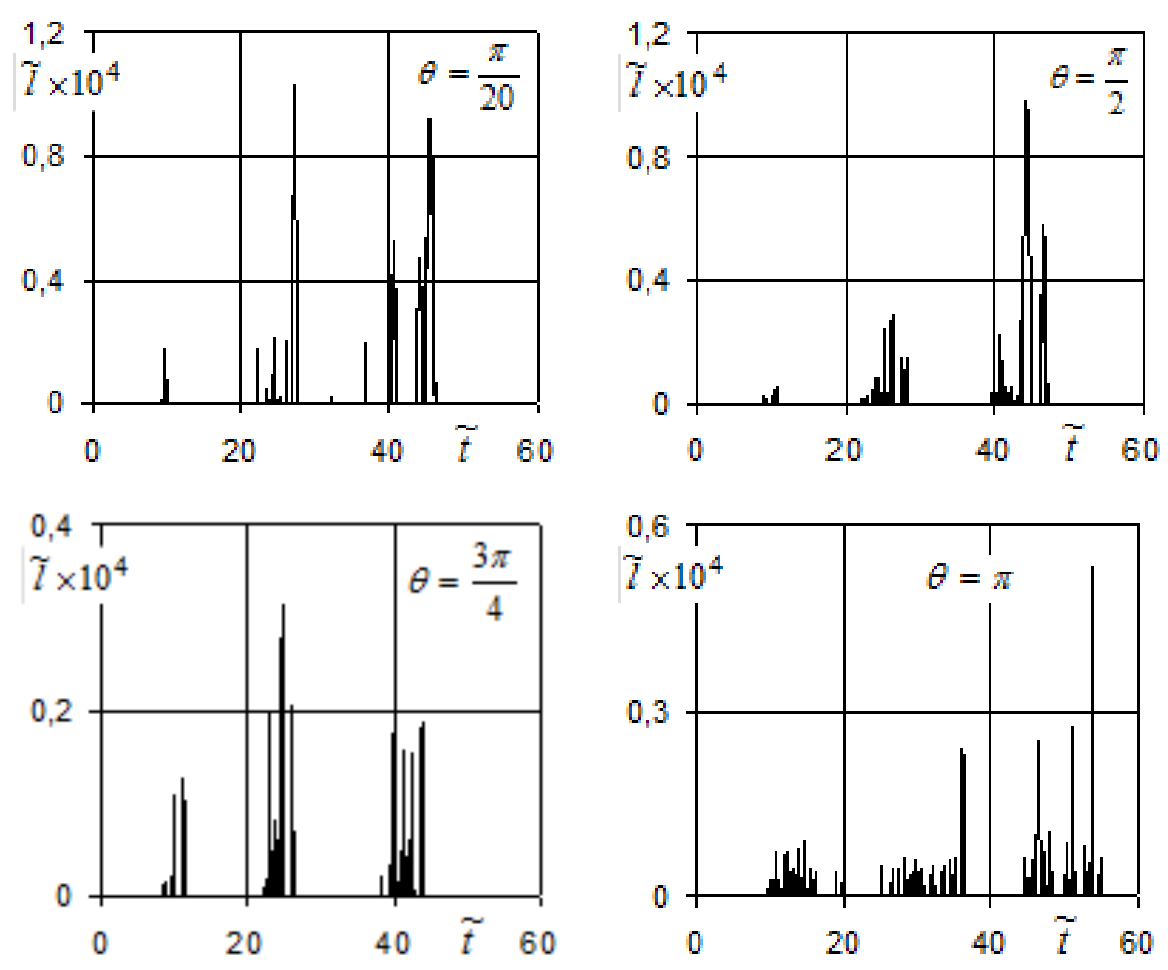

Figure 6. The thickness of the layer of the liquid separation from the shell when it is fixed near the north pole

Conclusions. The initial-boundary problem of the dynamics of hydroelastic system «cavity-liquid-shell-gas» in dimensionless form is developed and its solution using the finite difference method is constructed in this paper.

The investigation of the influence of shell thickness on its dynamics, stress intensity and formation of liquid separation from the shell is carried out. The investigation of the shell stressstrain state for its thickness $0,3 \cdot 10^{-3} \leq \tilde{\mathrm{h}} \leq 0,3 \cdot 10^{-2}$ is carried out, the dependences of radial displacements, the thickness of the separation layer, the stress intensity on the shell thickness are constructed. The asymmetric pulsations of the shell, which occur during its fixation, are considered, the comparison of the thickness of the separation layer for free and rigidly fixed shell is performed. During fixation, a significant increase in the amplitude of periodic processes in the shell and at its boundary are observed.

\section{References}

1. Yasniy P., Pyndus Y., Hud M. (2016) Analiz chastot i form vlasnykh kolyvan pidsylenykh tsylindrychnykh obolonok [Analysis of natural frequencies and shapes of stringer-stiffened cylindrical shells]. Scientific Journal of TNTU (Tern.), vol. 83, no 3, pp. 7-15. [In Ukrainian].

2. Yasniy P., Pyndus Y., Hud M. (2017) Methodology for the experimental research of reinforced cylindrical shell forced oscillations. Scientific Journal of TNTU (Tern.), vol. 86, no 2, pp. 7-13. [In English].

3. Mikulich O., Shvabjuk V. Investigation of the shock waves impact on the dynamic stress state of medium with the system of tunnel cavities. Vysnyk TNTU. T.: TNTU, 2017. Tom 87. 3. P. 7-15 https://doi.org/10.33108/visnyk_tntu2017.03.007

4. Sheptilevskiy A. V., Kosenkov V. M., Selezov I. T. Three-dimensional model of a hydroelastic system bounded by a spherical shell. Journal of Mathematical Sciences. Vol. 190. No. 6. 2013. https://doi.org/10.1007/s10958-013-1291-z

5. Krakovskaia E. V. O prylozhenyy teoryy obolochek k nekotorbm zadacham oftalmolohyy. Rossyiskyi zhurnal byomekhanyky. 2006. No. 1, pp. 52-58. 
6. Typiasev A. S. O deformatsyy sferycheskoi obolochky, zapolnennoi neszhymaemoi zhydkostiu, pry vozdeistvyy kruhovoho rastiazhenyia po эkvatoru. Rossyiskyi zhurnal byomekhanyky. 2008, tom 12, no. 2 (40), pp. 60-65.

7. Charalambopoulos A., Dassios G., Fotiadis D. I., Massalas C. V. Dynamic characteristics of the human skull-brain system. Mathematical and computer modelling. 27 (2). P. 81-101. https://doi.org/10.1016/S0895-7177(97)00261-6

8. Kuropatenko V. F., Andreev Yu. N. O modelyrovanyy dynamycheskykh protsessov v sferycheskykh y tsylyndrycheskykh obolochkakh. Vichyslytelnaia mekhanyka sploshnykh sred. 2010. T. 3. No. 4.

P. 53-67. https://doi.org/10.7242/1999-6691/2010.3.4.36

9. Advani S. H., Lee Y. C. Free vibrations of fluid-filled spherical shells. J. Sound and Vibr. 1970. 12. No. 4. P. 453-462.

10. Ali E. Vibrations of fluid-filled spherical shells. J. Acoust. Soc. Amer. 1969. Vol. 46. No. 1. Pt. 2. P. 186190. https://doi.org/10.1121/1.1911668

11. Fazelzadeh S. Ahmad, Esmaeal Ghavanloo Coupled axisymmetric vibration of nonlocal fluid-filled closed spherical membrane shell. Acta MechanicaSeptember. 2012. Vol. 223. Issue 9, pp 2011-2020. https://doi.org/10.1007/s00707-012-0692-2

12. Mingsion R. B., Kuorung W. Free vibration of a thin spherical shell containing a compressible fluid. J. Acoust. Soc. Amer. 1994. Vol. 95. No. 6. P. 3300-3310. https://doi.org/10.1121/1.409992

13. Shah S. A., Tajuddin M. On axially symmetric vibration of fluid filled poroelastic spherical shells. Open Journal of Acoustics. 2011. 1. P. 15-26. https://doi.org/10.4236/oja.2011.12003

14. Naugolnih K. A., Roy N. A. Elektrycheskye razryadi v vode. M.: Nauka, 1977. 151 p.

15. Prasad C. On vibrations of spherical shells. J. Acoust. Soc. Amer. 1964. 36. No. 3. P. $489-494$. https://doi.org/10.1121/1.1918982

16. Sheptylevskyi A. V., Selezov Y. T., Kosenkov V. M. Chyslennoe modelyrovanye nelyneinoi dynamyky gazovoi sferycheskoi polosty pry ee nachalnykh pulsatsyiakh v zhydkosty. Prykladnaia hydromekhanyka. 2015. No. 2. 17 (89). P. 70-77.

17. Xi L., Cen Z., Chen J. A Second-order Finite Difference Scheme for a Type of Black-Scholes Equation. Journal of Nonlinear Sciencs. 2008. Vol. 6. No. 3. P. 238-245.

18. Sheptylevskyi A. V., Kosenkov V. M. Pulsatsyy sferycheskoi obolochky s zhydkostiu pry vvode эnerhyy v tsentre. Prykladnaia hydromekhanyka. 2014. No. 1. 16 (88). P. 70-77. https://doi.org/10.1016/j.advwatres.2014.04.016

19. Sheptylevskyi A. V, Selezov Y. T., Kosenkov V. M. Dynamycheskoe kontaktnoe vzaymodeistvye upruhoi sferycheskoi obolochky y zapolniaiushchei eë zhydkosty s uchëtom kavytatsyy. Prykladnaia hydromekhanyka. 2013. No. 2.15 (87). P. 73-84.

\section{Список використаної літератури}

1. Ясній П. В., Пиндус Ю. І., Гудь М. І. Аналіз частот і форм власних коливань підсилених циліндричних оболонок. Вісник ТНТУ. 2016. Том 83. № 3. С. 7-15. (Механіка та матеріалознавство).

2. Yasniy P., Pyndus Y., Hud M. Methodology for the experimental research of reinforced cylindrical shell forced oscillations. Вісник ТНТУ. 2017. Том 86. № 2. С. 7-13. (Механіка та матеріалознавство).

3. Mikulich O., Shvabjuk V. Investigation of the shock waves impact on the dynamic stress state of medium with the system of tunnel cavities. Вісник ТНТУ. 2017. Том 87. № 3. С. 7-15. https://doi.org/10.33108/visnyk_tntu2017.03.007

4. Sheptilevskiy A.V. Sheptilevskiy A. V., Kosenkov V. M., Selezov I. T. Three-dimensional model of a hydroelastic system bounded by a spherical shell. Journal of Mathematical Sciences. Vol. 190. No. 6. 2013. https://doi.org/10.1007/s10958-013-1291-z

5. Краковская Е. В. О приложении теории оболочек к некоторым задачам офтальмологии. Российский журнал биомеханики. 2006. №1. С. 52-58.

6. Типясев А. С. О деформации сферической оболочки, заполненной несжимаемой жидкостью, при воздействии кругового растяжения по экватору. Российский журнал биомеханики. 2008. Том 12. № 2 (40). C. 60-65.

7. Charalambopoulos A., Dassios G., Fotiadis D. I., Massalas C. V. Dynamic characteristics of the human skull-brain system. Mathematical and computer modelling. 27 (2). P. 81-101. https://doi.org/10.1016/S0895-7177(97)00261-6

8. Куропатенко В. Ф., Андреев Ю. Н. О моделировании динамических процессов в сферических и цилиндрических оболочках. Вычислительная механика сплошных сред. 2010. Т. 3. № 4. С. 53-67. https://doi.org/10.7242/1999-6691/2010.3.4.36

9. Advani S. H., Lee Y. C. Free vibrations of fluid-filled spherical shells. J. Sound and Vibr. 1970. 12. № 4. P. 453-462. 
10. Ali E. Vibrations of fluid-filled spherical shells. J. Acoust. Soc. Amer. 1969. Vol. 46. № 1. Pt. 2. P. 186-190. https://doi.org/10.1121/1.1911668

11. Fazelzadeh S. Ahmad, Esmaeal Ghavanloo Coupled axisymmetric vibration of nonlocal fluid-filled closed spherical membrane shell. Acta MechanicaSeptember. 2012. Vol. 223. Issue 9, pp. 2011-2020. https://doi.org/10.1007/s00707-012-0692-2

12. Mingsion R. B., Kuorung W. Free vibration of a thin spherical shell containing a compressible fluid. J. Acoust. Soc. Amer. 1994. Vol. 95. № 6. P. 3300-3310. https://doi.org/10.1121/1.409992

13. Shah S. A., Tajuddin M. On axially symmetric vibration of fluid filled poroelastic spherical shells. Open Journal of Acoustics. 2011. 1. P. 15-26. https://doi.org/10.4236/oja.2011.12003

14. Наугольных К. А., Рой Н. А. Электрические разряды в воде. М.: Наука, 1977. 151 с.

15. Prasad C. On vibrations of spherical shells. J. Acoust. Soc. Amer. 1964. 36. № 3. P. 489-494. https://doi.org/10.1121/1.1918982

16. Шептилевский А. В., Селезов И. Т., Косенков В. М. Численное моделирование нелинейной динамики газовой сферической полости при ее начальних пульсациях в жидкости. Прикладная гидромеханика. 2015. № 2. 17 (89). С. 70-77.

17. Xi L., Cen Z., Chen J. A Second-order Finite Difference Scheme for a Type of Black-Scholes Equation. International Journal of Nonlinear Sciencs. 2008. Vol. 6. No. 3. P. 238-245.

18. Шептилевский А. В., Косенков В. М. Пульсации сферической оболочки с жидкостью при вводе энергии в центре. Прикладная гидромеханика. 2014. № 1. 16 (88). С. 70-77. https://doi.org/10.1016/j.advwatres.2014.04.016

19. Шептилевский А. В., Селезов И. Т., Косенков В. М. Динамическое контактное взаимодействие упругой сферической оболочки и заполняющей её жидкости с учётом кавитации. Прикладная гидромеханика. 2013. № 2. 15 (87). С. 73-84.

\title{
УДК 539.3
}

\section{ВПЛИВ ТОВЩИНИ ПРУЖНОЇ СФЕРИЧНОЇ ОБОЛОНКИ 3 РІДИНОЮ НА ЇЇ НАПРУЖЕНО-ДЕФОРМОВАНИЙ СТАН}

\section{Олексій Шептилевський}

\author{
Миколаӥвський національний аграрний університет, Миколаїв, Украӥна
}

\begin{abstract}
Резюме. Розглянуто динамічну систему, яка складається з пружної сферичної оболонки, заповненої рідиною з газовою порожниною в иеентрі. Газова порожнина є джерелом збудження системи при введені в неї енергії. Після вводу енергії газова порожнина збільшується, формуючи хвилю тиску в рідині, яка надходить до оболонки й таким чином система виходить зі стану рівноваги. Пульсації газової порожнини є иеетрально-симметричними та описуються рівнянням балансу енергіі. При розв'язуванні задачі взаємодії порожнини з рідиною враховано нелінійність пульсацій порожнини. Динаміка пружної сферичної оболонки визначається системою рівнянь ї̈ руху в сферичній системі координат. Система визначає залежність переміщень та кутів повороту серединної поверхні від зусиль та моментів. Побудову розв'язків системи виконано за допомогою числових методів. Алгоритм взаємодії рідини та оболонки виконано з урахуванням можливості відриву рідини від поверхні оболонки та утворення кавітаційної порожнини на границі розподілу середовищ. Досліджено вплив товщини оболонки та ї̈ закріплення на динаміку системи, зокрема стосовно впливу товщзини на амплітуду та інтенсивність пульсацій. Зі збільшенням товщчни оболонки зменшується амплітуда ї̈ пульсацій та їх інтенсивність, унаслідок чого значно ускладнюється відрив рідини від оболонки та утворення кавітаційної порожнини на границі розподілу середовищ. Розглянуто можливість моделювання закріплення частини поверхні оболонки та залежність ї̈ динаміки поблизу площяадки закріплення від зміни товщчни оболонки. При закріпленні спостерігалося значне підвищення тиску на границі та збільшення напружень оболонки в околі закріплення в певний момент часу внаслідок фокусування хвиль тиску на границі рідина - оболонка. Збільшення товщини оболонки призводить до зменшення інтенсивності переміщень та поворотів поверхні поблизу закріплення.
\end{abstract}

Ключові слова: гідропружність, газова порожнина, сферична хвиля, пружна сферична оболонка, взаємодія середовищ, відрив рідини, переміщення поверхні оболонки. 